\title{
International Financial Reporting Standard (IFRS) Adoption and Its Impact on Financial Reporting: Evidence from Listed Nigeria Oil and Gas Companies
}

\author{
Murtala Zakari \\ Post Graduate School of Accounting and Finance \\ Leeds Beckett University, Leeds, UK \\ E-mail: murhafs2010@gmail.com
}

Received: April 2, $2017 \quad$ Accepted: May 17, $2017 \quad$ Published: June 1, 2017

doi:10.5296/ajfa.v9i1.11407 URL: https://doi.org/10.5296/ajfa.v9i1.11407

\begin{abstract}
This study seeks to investigate the impact of IFRS adoption on financial reporting in Nigeria Oil and Gas sector; whether it leads to significant financial reporting improvement in terms of value addition and quality; whether it reduces information asymmetry and increases investors' confidence and understanding of the financial reports. To achieve this, data were collected from financial statements prepared using IFRS for the periods 2012-2016, and financial statements prepared using Nigeria GAAP for the periods 2007-2011, i.e. pre and post IFRS adoption in Nigeria for a period of 5years each. Analysis was conducted to test for the significance level of ROE, PAT/Sales, CA/CL, and debt-to-equity using mean, standard deviation of ratios, and T-test (paired) for both periods. The researcher found that Nigerian GAAP is more attractive and promising to shareholders than IFRS. In the same vein, IFRS is more attractive and promising to long term lenders than Nigerian GAAP. The study concludes that there is no significant financial reporting difference and quality in adopting IFRS compare to the Nigeria GAAP by the listed Oil and Gas companies of Nigeria.
\end{abstract}

Keywords: IFRS, Nigeria, Oil and Gas, Financial Reporting, Financial Statement 


\section{Introduction}

\subsection{General Background}

IFRS is an International Financial Reporting Standard issued by the International Accounting Standards Board (IASB), an independent organization registered in the United States of America (USA) but based in London, United Kingdom. They pronounce financial reporting standards that ideally would apply equally to financial reporting by public interest entities worldwide. Between 1973 and 2000, international standards were issued by the IASB's predecessor organization, the International Accounting Standards Committee (IASC), a body established in 1973 by the professional accountancy bodies in Australia, Canada, France, Germany, Japan, Mexico, Netherlands, United Kingdom and Ireland, and the U.S. During that period, the IASC's pronouncements were described as International Accounting Standards (IAS). Since April 2001, this rulemaking function has been taken over by a newly constituted IASB. The IASB describes its pronouncements under the label "International Financial Reporting Standards", though it continues to recognize the IAS issued by the defunct IASC (Deloitte, 2012). The adoption of IFRS in over 120 countries is an issue of global relevance among various countries of the world due to quest for uniformity, reliability and comparability of financial statements of companies. The benefit of adopting a standardized set of financials is to benchmark company performance against their peers, to allow global investors to compare firms globally (IASB, 2015).

Nigeria has joined the League of Nations reporting IFRS. With the adoption of IFRS in Nigeria, a lot stands to be gained from the seemingly distressed global economy. With successful implementation of IFRS, Nigeria will benefit economically by receiving a boost on foreign direct investments (FDIs) and increasing investors' confidence when investors are uncertain about the information available to them. By providing reliable and internationally comparable financial information, IFRSs are a very important fundamental of global market economy. The Federal Government of Nigeria formally announced its adoption and launched the roadmap for its implementation on 2 nd September 2010. The approval was seen as a milestone for Nigeria as it becomes a member state among those countries that have adopted IFRS. The roadmap for implementation mandates listed and significant public interest entities to prepare their financial statements using applicable IFRSs by December 31, 2012. At a seminar organized by Financial Reporting Council (FRC) formerly known as the 'Nigerian Accounting Standards Board', the former Minister of Trade and Commerce Martins-Kuye noted that the decision by government to adopt the global standards was due to its immense benefits, adding that apart from assurance of useful and meaningful decision on investment portfolio in the country, there would also be attraction of Foreign Investments. He noted that convergence would also create easier access to external capital; reduction in the cost of doing business across borders by eliminating the need for supplementary information from Nigerian companies; easier regulation of financial information in the country, and also enhance knowledge of global financial reporting standards by tertiary institutions, amongst others (Financial Reporting Council, 2012).

The proponents of IFRS are of the view that its benefits exceed the cost of compliance and 
that international accounting standards are superior to domestic standards (Ashbaugh and Pincus, 2001). This entails that with better accounting standards and greater transparency, investors would be more confident of the financial information available (Daske, 2006) and would have greater confidence in investing in equity markets. Higher quality of financial reporting will lead more investors and thus reduce the firm's cost of capital (Leuz, 2003; and Lambert et al., 2007).

There are significant differences between the Nigeria GAAP and IFRS, this involves a huge cost of transition and will change many accounting practices in the areas of revenue recognition, inventory valuations, current and non-current classification of assets, fixed assets accounting, business combination, etc. With the adoption and implementation of IFRS in Nigeria, the following principles will have to be followed; recognize and derecognize all assets and liabilities as required by IFRS; classify all assets and liabilities in accordance with IFRS; and measure all assets and liabilities in accordance with IFRS (IASB, 2015). All these requirements would involve a huge cost, and unless the benefits exceed the cost, IFRS adoption will not be meaningful.

This study aims to examine the benefits of adopting IFRS.The study seeks to investigate the impact of IFRS adoption on financial reporting in Nigeria Oil and Gas sector; whether it leads to significant financial reporting improvement in terms of value addition and quality; whether it reduces information asymmetry and increases investors' confidence and understanding of the financial reports.

Oil and Gas sector is chosen because it is the largest on the African continent, the sector is very important, as government revenues and foreign exchange heavily rely on this sector, it is the main stay of Nigeria economy and contributes up to 70\% of GDP and has been the focal point of attraction to both local and foreign investors, and to the researcher best knowledge, this has not been analyzed before.

The major contribution of this study is demonstrating the benefits of IFRS adoption using key financial ratios for the accounts prepared with Nigeria GAAP and IFRS, what would be interesting is the variability in the ratios. The study will enlighten readers and users of financial statements with new insights on IFRS adoption. It will also provide useful guidelines for effective measurement of the impact of IFRS adoption to researchers, preparers of financial statements, regulators, investors, and other stakeholders.

\subsection{Research Questions}

1. Does adopting IFRS lead to a significant difference in financial reporting quality?

2. Does adopting IFRS reduces information asymmetry and attract more investors?

\subsection{Research Objectives}

1. To assess if IFRS adoption in Nigeria leads to significant financial reporting difference in terms of improved earnings quality of investors. 
2. To determine if IFRS adoption in Nigeria reduces information asymmetry and increases investors' confidence and understanding of the financial reports in terms of comparability and investors' earning forecast.

\section{Literature Review}

In view of the seemingly inexorable rise of IFRS as the global accounting benchmark (Chua and Taylor, 2008) and critics' concerns over its uniform applicability and relevance to different institutional, political, and economic contexts (Cahan, Liu, and Sun, 2008), it is increasingly important to empirically examine the impact of IFRS adoption on accounting quality in countries of different contexts (Liu, et al. 2011). Global adoption of international accounting standards has been increasingly debated. Supporters of International Financial Reporting Standards (IFRS) argue that the use of IFRS increases the quality of financial reporting and benefits investors (Daske et al., 2008). Opponents argue that a single set of standards may not be suitable for all settings and thus may not uniformly improve value relevance and reliability due to differences among countries (Soderstrom and Sun, 2007). Empirical studies have mixed results on quality change after the adoption of IFRS in different countries. One of the inter-nationality dimensions is that the standard is not closely aligned with the economic or political institutions of any particular nation (Chua and Taylor, 2008), so there are arguments for assessment of IFRS practice on a country-by-country basis (Nobes, 2006).

The International Accounting Standards Committee (IASC) Foundation has documented the "need to have an understanding of the impact of IFRS as they are adopted in particular regions" (IASB, 2004, para. 93). There are advantages for developing countries to converge with IFRS which include rapid improvement in the perceived quality and status of financial reports (Tyrrall et al., 2007). Tendeloo and Vanstraelen (2005) argue that IFRS which are considered as high quality standards can be a condition for a high quality financial statement. The findings of the study do not fully support that companies adopting IFRS clearly show higher accounting quality after the compliance. After the adoption of the international accounting standards, several studies were carried out to assess the impact of such adoption on the capital market aiming to check whether the IFRS adoption had changed the accounting information. Barth et al. (2008) studied the information disclosed by companies in different countries before and after the convergence to the international accounting standards. The authors found evidences of improvement in the informational content after the IFRS adoption.

Emenyonu and Gray (1996), Dumontier and Raffournier (1998), El-Gazzar et al. (1999), and Murphy (1999) examine to what extent accounting disclosures and measures of companies applying IFRS have become harmonized and what motivates these companies to report using IFRS. They found that the decision to apply IFRS is driven by their financing policy and performance, multiple listing in various stock exchanges in different countries, and their foreign operations. Ashbaugh and Pincus (2001) conclude that financial reports using IFRS are better suited for forecasting and convergence in accounting policies by using IFRS improves the analyst's forecast of earnings and the quality of earnings. Street and Bryant 
(2000) and Ashbaugh and Pincus (2001) support these findings by identifying the differences between non-US companies reporting using IFRS or US GAAP. They conclude that companies use IFRS to provide more standardized information than financial reports prepared using national GAAP. The findings of Brochet et al. (2013) are consistent with earlier findings that IFRS adoption leads to capital market benefits of lesser return to insider as the financial results are more comparable, allowing all users to make a better comparison. The findings of Armstrong et al. (2010) support that IFRS adoption leads to positive reaction from investors for firms with high quality information. A greater positive impact on quality is documented for banking stocks. The overall findings support increase in information quality, decrease in asymmetry of information, more rigorous enforcement and convergence. According to Lee et al. (2010), the adoption of the international accounting standards increases the quality of information disclosed, thus reducing the information asymmetry and, consequently, the costs for analysis and decision-making by investors, reflecting directly in the reduction of capital cost of companies. Glaum et al. (2013) assesses the impact of the IFRS adoption in Germany on the accuracy of analysts' forecasts from 1997 to 2005. The results indicated a significant increase in analysts' accuracy after the international accounting adoption, suggesting that greater information disclosure affects the quality of forecast performed.

International accounting standard setters and accounting regulators who plan to converge with IFRS should assess the relevance of IFRS to their national needs. Nobes (1998 cited in Gray et al.,2001)makes a distinction between the needs of microeconomic and the needs of macroeconomic systems. Research has uncovered the major factors influencing the national need for accounting information. Such factors include strength of equity markets such as the relative size of the public and private sectors and the state of capital market development, the degree of similarity in economic and social environment to the original economy where an accounting system is developed, and the accounting needs and regulation of a nation (Chamisa, 2000; Nobesand Parker, 2006; Radebaugh et al., 2006; Tyrrall et al., 2007). Researchers including Cairns (1990) argue that IFRS are relevant to developing countries. Major disadvantages for developing countries to converge with IFRS such as "information overloads" (Choi and Mueller, 1984) and the additional cost of unnecessary complexity (Belkaoui, 2004) occur when IFRS are unsuited or irrelevant to national needs. Many researchers doubt the relevance of IFRS to developing countries. Xiang (1998) raises concerns over the relevance of IFRS to China. If IFRS are irrelevant, advantages such as improved accounting quality may not result from IFRS adoption or convergence.

This study extends prior research on IFRS adoption and adds to the literature by examining the relevance and impact of IFRS on financial reporting under rapid change in a major developing country like Nigeria.

\section{Research Methodology}

\subsection{Research Approach}

This research is guided by an overarching research philosophy of positivism. It is based on observable and measurable variables to search for patterns and causal relationships. The study 
uses a deductive approach because it is testing and expanding upon existing theoretical and empirical research. The advantage of using a deductive approach over an inductive approach is that it takes on a clearer structure and the methodology is easier to replicate which is important to achieve reliability (Saunders and Lewis, 2012). This descriptive study is based on quantitative analysis in order to achieve the desired research objectives. Quantitative research focuses on measurable, quantifiable data which is more generalizable than qualitative methods (Bell and Bryman, 2003).

The researcher utilizes longitudinal study using secondary data from the published annual reports and accounts of Nigeria Oil and Gas listed companies. This method is consistent with other research in the literature (Liu et al., 2011; Bodhanwala and Shernaz, 2016). The use of secondary data is justified by the fact that written or printed document are more accurate and reliable in ascertaining compliance to principles in research work than primary data gathered through personal interview or questionnaire administration (Dandago and Muktar, 2003 cited in Zakari, 2006)

\subsection{Research Design and Data Collection}

\subsubsection{Timeframe}

Two periods- pre and post IFRS adoption were studied. IFRS in Nigeria was adopted in 2012 financial year by the listed companies in preparing their accounts. However, before the adoption, Nigeria GAAP (SAS) was in used. This study covers 5years financial statements using Nigeria GAAP from 2007 - 2011, and 5years financial statements using IFRS from 2012 - 2016. The five years each represents a sufficient time period to factor in seasonality and full reporting cycles. (Ekatah et al., 2011, Bodhanwala and Shernaz, 2016)

\subsubsection{Population of the study}

The population of this study comprises of allthe ten (10) listed companies in the Oil and Gas sector of Nigeria.

\subsubsection{Sample of the study}

A reasonable size of the population in Nigeria Oil and Gas space wererandomly selected for the study. This includes; Total Nigeria Plc, Oando Plc, Forte Oil Plc, and Con Oil Plc. To achieve this, the names of the listed companies were written on pieces of papers and mixed up, each paper was picked without a replacement and each time a paper was picked, the remaining pieces of papers were reshuffled and mixed up again before picking the second one, this process continued until the required number of sample was made. This method is unbiased and gives every member of the population an equal chance of being selected and similar method was adopted by Zakari (2006) in arriving at his sample size.

\subsubsection{Data}

The companies covered in this study have financial statements using IFRS for the periods between 2012 and 2016. However, for comparisons, the periods between 2007 and 2011 in which the companies' annual reports were prepared using Nigeria GAAPwould be usedto test 
for the significance level of ROE, PAT/Sales, Current Asset/Current Liability, debt-to-equity using financial statement prepared with Nigeria GAAP and IFRS.

\subsubsection{Variables}

In this study, statistical test of comparing ratios related to shareholder (i.e., Return on Equity and profitability) and creditors (short- and long-term liquidity) is used to provide evidence if IFRS reporting leads to more meaningful ratios with less variability. The following ratios will be used as proxies for this study: ROE for shareholder, profitability for sales, current ratio for short-term liquidity, and debt-equity ratio for long-term liquidity. Financial statements prepared using Nigeria GAAP and IFRS would lead to different ratios; what would be interesting to study is the variability in ratios. In the literature, Bodhanwala and Shernaz (2016) adopted similar variables.

\section{Analysis and Discussion}

This section present statistical test of comparing ratios related to shareholder (i.e., Return on Equity and profitability) and creditors (short- and long-term liquidity) to provide evidence if IFRS reporting leads to more meaningful ratios with less variability.

Table 1. Mean Value of Ratios with Nigerian GAAP and IFRS

\begin{tabular}{|l|l|l|l|l|l|}
\hline Variables & $\mathrm{N}$ & Mean Nig. GAAP & $\begin{array}{l}\text { Mean } \\
\text { IFRS }\end{array}$ & t-test & P-Value \\
\hline ROE & 4 & 0.11 & 0.00 & 0.45 & 0.67 \\
\hline PAT/Sales & 4 & 0.04 & -0.91 & 1.02 & 0.35 \\
\hline CA/CL & 4 & 1.14 & 1.01 & 1.17 & 0.29 \\
\hline Debt/Equity & 4 & 0.24 & 0.31 & -0.37 & 0.73 \\
\hline
\end{tabular}

Source: SPSS output analyzed from financial reports of selected Oil \& Gas Companies

The above table 1 result depicts that there is no significant variability in the average ratios of ROE, PAT/Sales, CA/CL and Debt/Equity between Nigerian GAAP and IFRS of listed Oil and Gas companies of Nigeria because the p-values from the table are all greater than 0.05 level of significance, at 95\% confidence level. However, the mean values of ROE, PAT/Sales, CA/CL, Debt/Equity ratios for all the companies following Nigerian GAAP and IFRS are not significantly different. The p-values exceed the critical values for all the four variables. The proportion of companies that report higher ROE as per Nigerian GAAP than IFRS is around $67 \%$. This shows that Nigerian GAAP is more attractive and promising to shareholders than IFRS when it comes to calculation of ROE. In the same vein, ratio concerning long term lenders of funds (Debt/Equity), the proportion of companies that report higher Debt/Equity as per IFRS than Nigerian GAAP is $73 \%$.This shows that IFRS is more attractive and promising to long term lenders than Nigerian GAAP when it comes to calculation of Debt/Equity. 
Table 2. Standard Deviation of Ratios under Nigerian GAAP and IFRS

\begin{tabular}{|l|c|c|l|l|l|}
\hline & & \multicolumn{2}{|l|}{ Standard Deviation } & \multicolumn{2}{l|}{ Standard Error } \\
\hline Variables & $\mathrm{N}$ & \multicolumn{1}{|l|}{$\begin{array}{l}\text { Nig. } \\
\text { GAAP }\end{array}$} & IFRS & Nig. GAAP & IFRS \\
\hline ROE & 4 & 0.26 & 0.38 & 0.13 & 0.19 \\
\hline PAT/Sales & 4 & 0.07 & 1.85 & 0.04 & 0.93 \\
\hline CA/CL & 4 & 0.19 & 0.13 & 0.10 & 0.07 \\
\hline Debt/Equity & 4 & 0.26 & 0.22 & 0.13 & 0.11 \\
\hline
\end{tabular}

Source: SPSS output analyzed from financial reports of selected Oil \& Gas Companies

The above table 2 result depicts that mean values of standard deviation of the ratios are also not significantly different. Looking at the second ratio concerning shareholders (i.e PAT/Sales), the proportion of cases where standard deviation is higher as per IFRS is around 93\%. This shows that IFRS is more attractive and promising to shareholders than Nigerian GAAP when it comes to calculation of PAT/Sales.

\section{Conclusion}

This research finds that there is no significant variability in the average ratios of ROE, PAT/Sales, CA/CL and Debt/Equity between Nigerian GAAP and IFRS of listed Oil and Gas companies in Nigeria. This research finding means that IFRS reporting does not have higher accounting quality and reporting impact for shareholders, short and long term lenders of fund. The finding is consistent with that of (Bodhanwala and Shernaz, 2016; Tendeloo and Vanstraelen, 2005). The findings suggest that Nigerian GAAP is more attractive and promising to shareholders than IFRS. In the same vein, IFRS is more attractive and promising to long term lenders than Nigerian GAAP. The finding to the research questions of this study shows that there is no significant financial reporting difference and quality in adopting IFRS compare to the Nigeria GAP. This study has a number of limitations, which could be used to further research into the area. The study focuses on limited variables and sample as well as limited accounting reports. Further research could be done into other balance sheet positions regarding inventories and net working capital and for a longer times span.

\section{References}

Armstrong, C., Barth, M., and Riedl, E. (2010). Market Reaction to the Adoption of IFRS in Europe. The Accounting Review, pp. 31-61.

Ashbaugh, H., \& Pincus, M. (2001). Domestic Accounting Standards InternationalAccounting and the Predictability of Earnings. Journal of Accounting Research, 417-434. https://doi.org/10.1111/1475-679X.00020

Barth, M., Landsman, W. R., \& Lang, M. H. (2008). International Accounting Standards and 
Accounting Quality. Journal of Accounting Research, 46(3), 467-498. https://doi.org/10.1111/j.1475-679X.2008.00287.x

Belkaoui, A. (2004). Accounting theory. London, England: Thomson Publishers, 5th Ed.

Bell, E., \& Bryman, A. (2003). Business research methods. United States, Oxford University PressInc., New York.

Bodhanwala, R.J., \& Shernaz, B. (2016). IFRS Adoption and Its Impact on Indian Stocks: Evidence from IFRS-Compliant Indian Companies. The IUP Journal of Accounting Research \& Audit Practices, $X V(3)$.

Brochet, F., Jagolinzer, A., \& Riedl, E. (2013). Mandatory IFRS Adoption and Financial Statement. Contemporary Accounting Research, 30(4), 1373-1400.

Cahan, S. F., Liu, G., \& Sun, J. (2008). Investor Protection, Income Smoothing, and Earnings Informativeness. Journal of International Accounting Research, 7, 1-24. https://doi.org/10.2308/jiar.2008.7.1.1

Cairns, D. (1990, March). Aid for the Developing World. Accountancy, 82-85

Chamisa, E. E. (2000). The Relevance and Observance of the IASC Standards in Developing Countries and the particular case of Zimbabwe. International Journal of Accounting, 35, 267-286. https://doi.org/10.1016/S0020-7063(00)00049-2

Choi, F., and Mueller, G. (1984). International accounting”. Englewood Cliffs, NJ: Prentice Hall.

Chua, W. F., \& Taylor, S. L. (2008). The Rise and Rise of IFRS: An Examination of IFRS Diffusion. Journal of Accounting and Public Policy, 27, 462-473. https://doi.org/10.1016/j.jaccpubpol.2008.09.004

Daske, H. (2006). Economic Benefits of Adopting IFRS or US-GAAP- Have the Expected Costs of Equity Capital Really Decreased? Journal of Business Finance and Accounting, 33(3-4), 329-373. https://doi.org/10.1111/j.1468-5957.2006.00611.x

Daske, H., Hail, L., Leuz, C., \& Verdi, S. R. (2008). Mandatory IFRS Reporting Around the World: Early Evidence on the Economic Consequences. Journal of Accounting Research, 46(12), 1085-1142. https://doi.org/10.1111/j.1475-679x.2008.00306.x

Deloitte (2012). IFRS Adoption in Nigeria \& Optimizing the Gains of Global Investment Climate. (On line) Available from:

https://www.wecadeloitte.com/extranet/data/ifrsacademy/content/pdf (May 20, 2017)

Dumontier, P., \& Raffournier, B. (1998). Why Firms Comply Voluntarily with IAS: An Empirical Analysis with Swiss Data. Journal of International Financial Management and Accounting, 9(3), 216-245.

El-Gazzar, Finn, P., \& Jacob, R. (1999). An Empirical Investigation of Multinational Firms' Compliance with International Accounting Standards. the International Journal of 
Accounting, 34(2), 239-248.

Emenyonu, E., \& Gray, S. J. (1996). International Accounting Harmonization and the Major Developed Stock Market Countries: An Empirical Study. The International Journal of Accounting, pp. 269-279. https://doi.org/10.1016/S0020-7063(96)90020-5

Financial Reporting Council (2012). Financial Reporting Council of Nigeria - Overview of Its Regulatory Framework as It Relates to Companies (On line) Available from: http://www.lpc-ng.com/financial-reporting-council-of-nigeria-overview-of-its-regulatory-fra mework-as-it-relates-to-companies (May 20, 2017)

Francesco, B., \& Raynolde, P. (2011). The Determinants and Consequences of Heterogeneous IFRS Compliance Levels Following Mandatory IFRS Adoption: Evidence from a Developing Country. Journal of International Accounting Research, 11(1), 83-109.

Glaum, M., Baetge, J., Grothe, A., \& Oberdörster, T. (2013). Introduction of International Accounting Standards, Disclosure Quality Accuracy of Analysts' Earnings Forecasts. European Accounting Review, 22(1), 79-116. https://doi.org/10.1080/09638180.2011.558301

Gray, S. J., Salter, S. B., \& Radebaugh, L. H. (2001). Global accounting and control: A managerial emphasis. New York, NY: John Wiley

IASB (2004). IFRS para. 93. (Online) Available from: http://www.ifrs.org/Use-around-the world/Pages/Analysis-of-the-IFRS-jurisdictional-profiles.aspx (May 22, 2017)

IASB (2015), IFRS. (Online) Available from: http://www.ifrs.org/Use-around-theworld/Pages/Analysis-of-the-IFRS-jurisdictional-profiles.aspx (May 22, 2017)

Lambert, R., Leuz, C., \& Verrecchia, R. (2007). Accounting Information, Disclosure, and the Cost of Capital. Journal of Accounting Research, 45(2), 385-420.

Lee, E., Walker, M., \& Christensen, H. B. (2010). Mandating IFRS: Its Impact on the Cost of Equity Capital in Europe. Journal of International Accounting Research, 9(1), 143-168. https://doi.org/10.2308/jiar.2010.9.1.58

Leuz, C. (2003). IAS versus US GAAP: Information Asymmetry-Based Evidence from Germany's New Market. Journal of Accounting Research, 41(3), 427-445. https://doi.org/10.2307/2672910

Leuz, C., \& Verrecchia, R. (2000). The Economic Consequences of Increased Disclosure. Journal of Accounting Research, 38(Suppl.), 91-124.

Li, S. (2010). Does Mandatory Adoption of International Financial Reporting Standards in the European Union Reduce the Cost of Equity Capital? The Accounting Review, 85(2), 607-636. https://doi.org/10.2308/accr.2010.85.2.607

Liu, C., Yao, L.J., Hu, N., \& Liu, L. (2011). The Impact of IFRS on Accounting Quality in a Regulated Market: An Empirical Study of China. Journal of Accounting, Auditing \& Finance, 26(4), 659-676. https://doi.org/10.1177/0148558x11409164 


\section{Macrothink}

Asian Journal of Finance \& Accounting ISSN 1946-052X 2017, Vol. 9, No. 1

Mark, D., Xuesong, H., Mingyi, H., \& Siqi. (2011). The Impact of Mandatory IFRS Adoption on Foreign Mutual Fund Ownership: The Role of Comparability. Journal of Accounting \& Economics, 240-258.

Murphy, A.B. (1999). Firm Characteristics of Swiss Companies that Utilize International Accounting Standards. International Journal of Accounting, Vol. 34(1), 115-128. https://doi.org/10.1016/S0020-7063(99)80006-5

Nobes, C. (1998). Towards a General Model of the Reasons for International Differences in Financial Reporting. Abacus, 34, 162-187. https://doi.org/10.1111/1467-6281.00028

Nobes, C. (2006). The Survival of International Differences under IFRS: Towards a Research Agenda. Accounting and Business Research, 36, 233-245. https://doi.org/10.1080/00014788.2006.9730023

Nobes, C., \& Parker, R. (2006). Comparative International Accounting, Harlow, England: Pearson Education, 9th edition.

Radebaugh, L., Gray, S., \& Black, E. (2006). International accounting and multinational enterprises, Hoboken, NJ: John Wiley. 4th edition

Saunders, M. Lewis, P. (2012). Doing research in business and management: An essential guide to planning your project. Pearson Education Limited. $5^{\text {th }}$ edition

Soderstrom, N. S., \& Sun, K. J. (2007). IFRS Adoption and Accounting Quality: A Review. European Accounting Review, 16(4), 675-702. https://doi.org/10.1080/09638180701706732

Street, D., \& Bryant, S. (2000). Disclosure Level and Compliance with IASs: A Comparison of Companies with and Without US Listings and Filings. The International Journal of Accounting, pp. 305-329.

Tendeloo, V., \& Vanstraelen (2005). Earnings Management under German GAAP and IFRS. The European Accounting Review, 14(1), 155-180.

Tyrrall, D., Woodward, D., \& Rakhimbekova, A. (2007). The Relevance of International Financial Reporting Standards to a Developing Country: Evidence from Kazakhstan. International Journal of Accounting, 42, 82-110. https://doi.org/10.1016/j.intacc.2006.12.004

Xiang, B. (1998). Institutional Factors Influencing China's Accounting Reforms and Standards". Accounting Horizons, Vol.12, pp.105-119.

Zakari, M. (2006). “An Assessment of Depreciation Practice in Nigeria Commercial Banks". Unpublished project, for a partial fulfillment for the award of bachelor degree, Bayero University Kano, Nigeria 